\title{
ECOLOGICAL STATUS ASSESSMENT OF THE SAMOKOVSKA RIVER - 2018 CASE STUDY
}

\author{
Snežana B. Simić*, Aleksandra B. Mitrović, Nevena B. Đorđević, Sanja S. Radosavljević \\ University of Kragujevac, Faculty of Science, Department of Biology and Ecology, \\ Radoja Domanovića 12, 34000 Kragujevac, Serbia \\ *Corresponding author; E-mail: snezana.simic@pmf.kg.ac.rs \\ (Received March 29, 2021; Accepted April 21, 2021)
}

\begin{abstract}
The Samokovska River, as the most important watercourse of the Kopaonik National Park, has been poorly investigated from algological and water quality aspects. This river is not covered by the monitoring program of the Serbian Environmental Protection Agency routine. Our research performed in October 2018 aimed to present an algal diversity, ecological status assessment, and negative anthropogenic impacts threatening this river. For ecological status assessment purposes, the diatom indices phytobenthos and physico-chemical parameters of water were used. The typology and the problem of reliable assessing of the ecological status were also discussed on the example of the Samokovska River.
\end{abstract}

Keywords: Kopaonik, water quality, benthic algae, macroalgae, threatening factors, river typology.

\section{INTRODUCTION}

Due to the Law on National Park Kopaonik dating from 1981 (ANONYMOUS, 1981), this mountain was declared to be a National Park and was put under the country's protection as global common goods. The Samokovska River is the main watercourse on Kopaonik. It covers the area of 66.66 ha. As a part of the National Park, the Samokovska River has a privileged status of being a nature reserve (VASOVIĆ, 1988).

The Samokovska River was poorly investigated from algological and water quality aspects. The first, as well the only literature data on the algological and saprobiological research of this river date from the 1990s (LAUŠEVIĆ 1992, 1993; LAUŠEVIĆ and CVIJAN 1996). Thereafter, presence of some benthic macroalgae in the Samokovska River was reported by SIMIĆ (2002), Simić et al. (2003), and SiMIĆ and ĐORĐEVIĆ (2017).

According to the National Regulations (ANONYMOUS, 2010b, 2011b), all Serbian surface waters are classified into six types according to the criteria for water bodies typology such as geology, basin surface area, altitude, and type of substrate as the auxiliary parameter: Type 1 - large lowland rivers with domination of fine substrate; Type 2 - large rivers with domination of medium sized substrate, excluding rivers of Pannonian Basin; Type 3 - small and medium rivers, up to $500 \mathrm{~m}$ altitude and domination of large substrate granulation; Type 
4 - small and medium rivers at altitude above $500 \mathrm{~m}$ and domination of large granulated substrate; Type 5 - Pannonian Basin rivers, excluding rivers from Type 1; Type 6 - small watercourses outside the Pannonian Basin area not being included in Types 3 and 4, as well as the watercourses not encompassed by the National Regulation (ANONYMOUS, 2010b). Since the Samokovska River is not covered by the National Regulation (ANONYMOUS, 2010b), it belongs to the water bodies of Type 6 . However, according to the previously mentioned criteria for water bodies' typology, the Samokovska River can be placed to the water body Type 4.

For ecological status assessment of surface water, use of phytobenthos community parameters is recommended by Water Framework Directive (WFD, 2000). Although the term phytobenthos relates to all algae inhabiting the bottom of aquatic ecosystems, the National Regulation (ANONYMOUS, 2011b) comprises parameters of ecological status assessment based on IPS - "Indice de pollution-sensibilite" (CEMAGREF, 1982) and CEE - "Comission for Economical Community metric" (DESCY and COSTE, 1991) diatom indices. Diatoms are widely recognized as bioindicators of water quality because of their worldwide distribution, ability to inhabit various habitats, to be present in aquatic ecosystems throughout the year, and very quick responses to changes in environmental conditions (MCCORMIC and CAIRNS, 1994; POIKANE et al., 2016).

This paper aimed to present an algological diversity and ecological status assessment of the Samokovska River, as well as to indicate the problematic typology of water bodies on the example of this river.

\section{MATERIALS AND METHODS}

The field research on the Samokovska River were performed on the $31^{\text {st }}$ of October 2018 on five localities.

\section{Description of localities}

Locality S1 (Figure 1A) on the Samokovska River is positioned at the excursion site Kadijevac (N 4319'29.1", E 2045'67.3", elevation $1421 \mathrm{~m}$ ). The locality is placed on granitic geological substratum whereas the neighbouring vegatation consists of spruce forests and peat bogs. The locality is situated in the second degree protection zone (ANONYMOUS, 2016).

Locality S2 (Figure 1B) on the Samokovska River lies on the water intake of derivative small hydropower plant (HPP) "Samokovska reka 1" (Figure 1C) (N 43¹9'29.3", E $20^{\circ} 45^{\prime} 47.6^{\prime \prime}$, elevation $\left.1411 \mathrm{~m}\right)$. The locality is situated on granitic geological substratum and there is a sparse spruce forest around the water intake of the small HEPP. The small HPP "Samokovska reka 1" was built in 2017 with a water intake set in the riverbed of the Samokovska River. The underground pipes start from the water intake of the HPP and they mostly pass through the protected zone of the National Park Kopaonik. The water is conducted through the pipes to the plant room placed at the entrance of the National park from the direction of Jošanička Spa. Locality S2 is positioned in the second degree protection zone (ANONYMOUS, 2016).

Locality S3 (Figure 1D) is situated $300 \mathrm{~m}$ downstream from the water intake of the small HPP "Samokovska reka 1" (N 4319'31", E 2045'41.8", elevation $1408 \mathrm{~m})$. The locality is placed on granitic geological substratum whereas the neighbouring vegetation consists of a thick spruce forest. Locality S3 is positioned in the second degree protection zone (ANONYMOUS, 2016).

Locality S4 (Figure 1E) is placed $500 \mathrm{~m}$ upstream from plant room of the small HPP (N 4321'35.3", E 2044'25.3", elevation $994 \mathrm{~m}$ ). While leaving the gorge, the river flows 
through open space with no complete shade made by vegetation. Deciduous forests of Fagus silvatica dominate here. Locality $\mathrm{S} 4$ is positioned in the second degree protection zone (ANONYMOUS, 2016).

Locality S5 (Figure 1F) lies in Jošanička Spa (N 4323'18.3", E 2045'0.42", elevation $652 \mathrm{~m}$ ). The Samokovska River flows through the mixed forest. There is a restaurant on the right river bank just before the mouth of the Samokovska River into the Jošanička River. Locality S5 is not within boundaries of the National Park Kopaonik (ANONYMOUS, 2016).
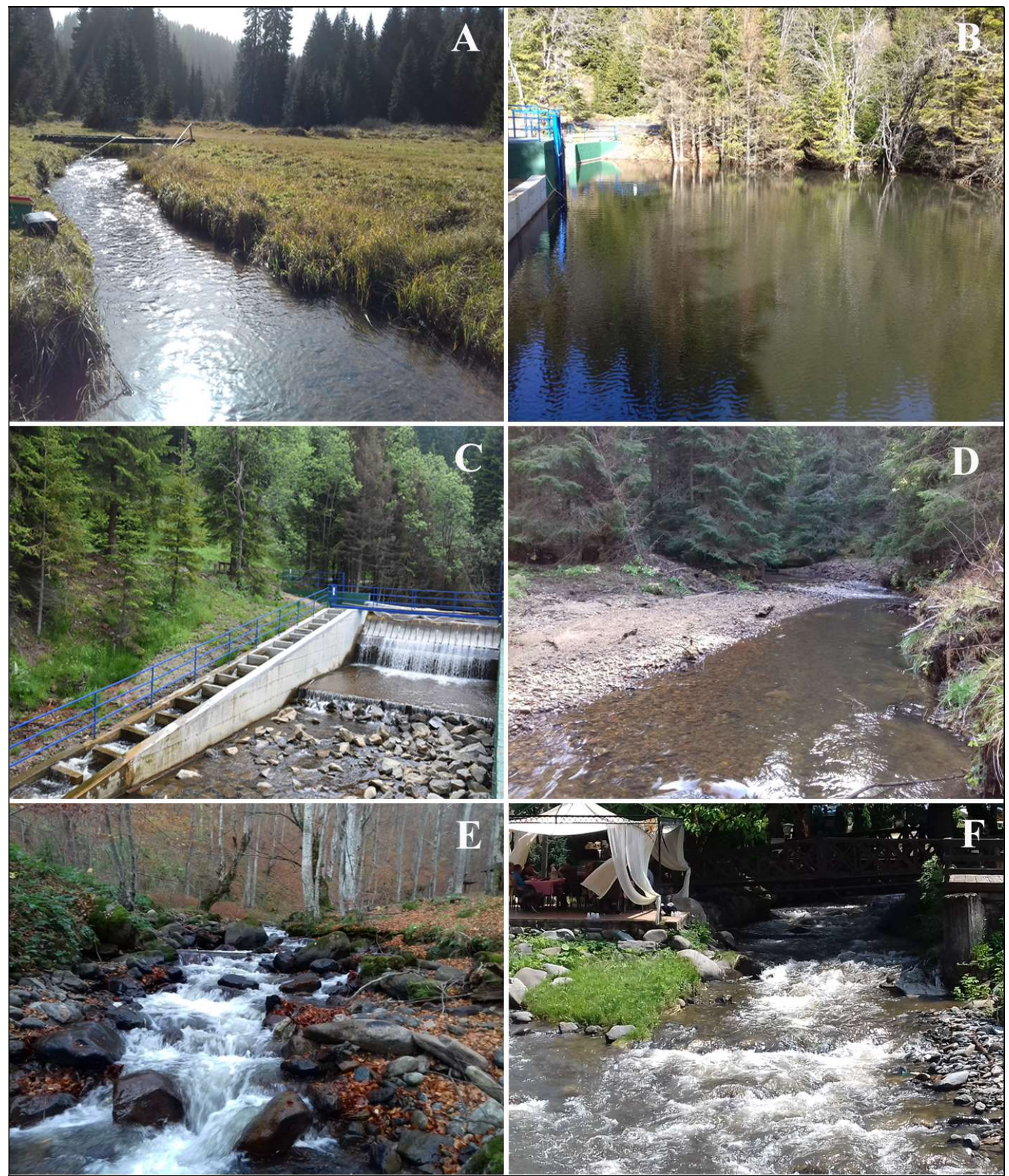

Figure 1. A - locality S1; B - locality S2 (photos by A. Mitrović, 2018);

C - dam of the small HPP "Samokovska reka 1" (photo by S. Simić, 2018);

D - locality S3; E - locality S4; F - locality S5 (photos by S. Radosavljević, 2018). 


\section{Sample collection}

The samples of benthic algae on S1, S3, S4, and S5 were collected dependent on the types of morphological forms and substratum (by tweezers, scraping from rocks, by pipettes on sand surfaces). The samples of epilithic diatoms for ecological status estimation were collected according to standard EN 13946, 2015. The phytoplankton sample for qualitative analysis at the S2 locality was collected by plankton net $(\varnothing 22 \mu \mathrm{m})$. The collected algal material was fixed in $4 \%$ formaldehyde solutuon and it was stored at the Department of Biology and Ecology of the Faculty of Science, University of Kragujevac.

The analysis of the collected algal material was performed under the light microscope Motic BA310 at 4x, 10x, 40x and 100x magnification (oil immersion). The microphotographs of found taxa were taken by digital camera BRESSER (9MP) and by using the software package MicroCamLab. Succeeding the measurement of morphological parameters, the identification of recorded taxa was performed according to KOMÁREK and ANAGNOSTIDIS (1999, 2005), KRIZMANIĆ (2009), ElORANTA et al. (2011), JOHN et al. (2011), ANDREJIĆ (2012), WeHr et al. (2015), PredojeviĆ (2017), and JAKOVLJEVić (2019).

Quantification of diatoms is performed under the light microscope until the defined number of undamaged valves is reached (400) by using the transect method according to the standard (EN 14407, 2015). Based on qualitative and quantitative epilithic diatoms analysis, diatom indices were calculated using OMNIDIA software (LECOINTE et al., 1993).

\section{Measurements of physical and chemical parameters of water}

Physical and chemical parameters of the water were measured according to the standard EN 5667 1-19, 2017. In determining physical characteristics of the water, at each locality the direct measurements of temperature $\left({ }^{\circ} \mathrm{C}\right)$ and conductivity $\left(\mu \mathrm{s} / \mathrm{cm}^{3}\right)$ were done, whereas the chemical properties measured directly on the field included the data on dissolved oxygen concentration (mg/l), oxigen saturation (\%), $\mathrm{pH}$ and hardness (mg/l). By using colorimeter, the concentrations of phosphate $(\mathrm{mg} / \mathrm{l})$, nitrate $(\mathrm{mg} / \mathrm{l})$, and ammonia $(\mathrm{mg} / \mathrm{l})$ were determined in the Laboratory of the Center for Fishery and Biodiversity Conservation of Inland Waters - Aquarium, Faculty of Science, University of Kragujevac.

\section{Ecological status assessment}

The ecological status of the Samokovska River was assessed using epilithic diatoms (IPS and CEE diatom indices) and supporting physico-chemical quality elements, both for water bodies belonging to Types 6 and 4. According to the National Regulation (ANONYMOUS, 2011b), for Type 4, calculation of two diatom indices - IPS and CEE is obligatory, in contrast to the Type 6 , for which only IPS index is required. Threshold values of these diatom indices between classes for all waterbody types are prescribed in the National Regulation (Table 1) (ANONYMOUS, 2011b).

\section{Threatening factors}

Possible threat factors were determined at each locality by visual analysis. 
Table 1. Threshold values of IPS and CEE diatom indices for six types, according to the National

Regulation (Anonymous, 2011b)

\begin{tabular}{|c|c|c|c|c|}
\hline \multirow[t]{2}{*}{$\begin{array}{l}\text { Diatom } \\
\text { indices }\end{array}$} & \multicolumn{4}{|c|}{$\begin{array}{c}\text { Threshold values between } \\
\text { ecological status classes }\end{array}$} \\
\hline & I-II & II-III & III-IV & IV-V \\
\hline \multicolumn{5}{|c|}{ Type 1} \\
\hline IPS & 14 & 10 & 8 & 6 \\
\hline CEE & 12 & 9 & 7 & 5 \\
\hline \multicolumn{5}{|c|}{ Type 2} \\
\hline & I-II & II-III & III-IV & IV-V \\
\hline IPS & 16 & 14 & 12 & 9 \\
\hline CEE & 12 & 9 & 7 & 5 \\
\hline \multicolumn{5}{|c|}{ Type 3} \\
\hline & I-II & II-III & III-IV & IV-V \\
\hline IPS & 16 & 14 & 12 & 9 \\
\hline CEE & 12 & 9 & 7 & 5 \\
\hline \multicolumn{5}{|c|}{ Type 4} \\
\hline & I-II & II-III & III-IV & IV-V \\
\hline IPS & 16 & 14 & 12 & 9 \\
\hline CEE & 12 & 9 & 7 & 5 \\
\hline \multicolumn{5}{|c|}{ Type 5} \\
\hline & I-II & II-III & III-IV & IV-V \\
\hline IPS & 14 & 10 & 8 & 6 \\
\hline CEE & 12 & 9 & 7 & 5 \\
\hline \multicolumn{5}{|c|}{ Type 6} \\
\hline & I-II & II-III & III-IV & IV-V \\
\hline IPS & 14 & 10 & 8 & 6 \\
\hline
\end{tabular}

\section{RESULTS AND DISCUSSION}

\section{Analysis of physical and chemical parameters of water}

Physical and chemical parameters of water at investigated localities of the Samokovska River indicate that water was cold, low-mineralized, soft, and well-aerated (Table 2). At the localities at higher altitudes, located in coniferous forests, $\mathrm{pH}$ was slightly acid, while at lower altitudes, it was slightly alkaline (Table 2). Nutrient enrichment was low, except regarding phosphates at S3, S4, and S5 localities, which concentrations were increased (Table 2).

\section{Algal diversity}

During researching in autumn 2018, a total of 79 taxa belonging to 5 phyla were recorded in the Samokovska River: Cyanobacteria - 10, Rhodophyta - 1, Ochrophyta (Xanthophyceae) -1 , Bacillariophyta -63 , and Chlorophyta -4 . The highest species richness was recorded at S1 (55 taxa), while the lowest was recorded at S2 locality (12 taxa) (Table 3). Only a few diatom representatives were recorded in the phytoplankton sample (S2) (Table 3), where the phytoplankton community has not yet been formed. 
Table 2. Physical and chemical parameters of water of the Samokovska River in October 2018

\begin{tabular}{|c|c|c|c|c|c|}
\hline Locality & S1 & $\mathbf{S 2}$ & S3 & S4 & S5 \\
\hline Temperature $\left({ }^{\circ} \mathrm{C}\right)$ & 6.2 & 6.6 & 6.5 & 9.1 & 10.2 \\
\hline Conductivity $\left(\mu \mathrm{s} / \mathrm{cm}^{3}\right)$ & 50 & 50 & 50 & 80 & 160 \\
\hline Water hardness (mg/l) & 20 & 20 & 20 & 40 & 70 \\
\hline $\mathrm{pH}(0-14)$ & 6.91 & 6.97 & 6.98 & 7.55 & 7.69 \\
\hline Dissolved oxygen $(\mathrm{mg} / \mathrm{l})$ & 10.96 & 10.87 & 10.89 & 11.15 & 11.06 \\
\hline Oxygen saturation $(\%)$ & 105.5 & 100 & 96.6 & 105.2 & 103.9 \\
\hline Nitrates $(\mathrm{mg} / \mathrm{l})$ & $\begin{array}{c}\mathrm{N}<1 \\
\mathrm{NO}_{3}<4\end{array}$ & $\begin{array}{c}\mathrm{N}<1 \\
\mathrm{NO}_{3}<4\end{array}$ & $\begin{array}{c}\mathrm{N}<1 \\
\mathrm{NO}_{3}<4\end{array}$ & $\begin{array}{c}\mathrm{N}<1 \\
\mathrm{NO}_{3}<4\end{array}$ & $\begin{array}{c}\mathrm{N}<1 \\
\mathrm{NO}_{3}<4\end{array}$ \\
\hline Phosphates (mg/l) & $\begin{array}{c}\mathrm{PO}_{4}<0.06 \\
\mathrm{P}<0.02 \\
\mathrm{P}_{2} \mathrm{O}_{5}<0.05\end{array}$ & $\begin{array}{c}\mathrm{PO}_{4}<0.06 \\
\mathrm{P}<0.02 \\
\mathrm{P}_{2} \mathrm{O}_{5}<0.05\end{array}$ & $\begin{array}{c}\mathrm{PO}_{4}=0.41 \\
\mathrm{P}=0.13 \\
\mathrm{P}_{2} \mathrm{O}_{5}=0.31\end{array}$ & $\begin{array}{c}\mathrm{PO}_{4}=0.15 \\
\mathrm{P}=0.05 \\
\mathrm{P}_{2} \mathrm{O}_{5}=0.11\end{array}$ & $\begin{array}{c}\mathrm{PO}_{4}=0.12 \\
\mathrm{P}=0.04 \\
\mathrm{P}_{2} \mathrm{O}_{5}=0.09\end{array}$ \\
\hline Ammonium (mg/l) & $\begin{array}{c}\mathrm{N}<0.02 \\
\mathrm{NH}_{4}<0.03 \\
\mathrm{NH}_{3}<0.02\end{array}$ & $\begin{array}{c}\mathrm{N}<0.02 \\
\mathrm{NH}_{4}<0.03 \\
\mathrm{NH}_{3}<0.02\end{array}$ & $\begin{array}{c}\mathrm{N}<0.02 \\
\mathrm{NH}_{4}<0.03 \\
\mathrm{NH}_{3}<0.02\end{array}$ & $\begin{array}{c}\mathrm{N}<0.02 \\
\mathrm{NH}_{4}<0.03 \\
\mathrm{NH}_{3}<0.02\end{array}$ & $\begin{array}{c}\mathrm{N}<0.02 \\
\mathrm{NH}_{4}<0.03 \\
\mathrm{NH}_{3}<0.02\end{array}$ \\
\hline
\end{tabular}

Table 3. Qualitative analysis of algae from the Samokovska River in October 2018.

\begin{tabular}{|c|c|c|c|c|}
\hline Localities & S1 & S3 & S4 & S5 \\
\hline \multicolumn{5}{|l|}{ Cyanobacteria } \\
\hline Chama siphon incrustans Grunow & + & + & & + \\
\hline Chamaesiphon polonicus (Rostafinski) Hansgirg & & & & + \\
\hline Leptolyngbya notata (Schmidle) Anagnostidis \& Komárek & + & + & + & + \\
\hline $\begin{array}{l}\text { Microcoleus autumnalis (Gomont) Strunecky, Komárek \& } \\
\text { J.R.Johansen }\end{array}$ & + & + & & \\
\hline $\begin{array}{l}\text { Microcoleus favosus (Gomont) Strunecky, Komárek \& } \\
\text { J.R.Johansen }\end{array}$ & + & + & & \\
\hline Oscilatoria sp. & & + & & \\
\hline Oscillatoria limosa C. Agardh ex Gomont & + & + & + & \\
\hline Planktolyngbya sp. & + & + & & + \\
\hline Phormidium spp. & + & & + & \\
\hline Tolypothrix sp. & + & & & \\
\hline \multicolumn{5}{|l|}{ Rhodophyta } \\
\hline Audouinella chalybea (Roth) Bory & + & + & + & + \\
\hline \multicolumn{5}{|l|}{ Ochrophyta (Xanthophyceae) } \\
\hline Vaucheria sp. & + & & & \\
\hline \multicolumn{5}{|l|}{ Bacillariophyta } \\
\hline Achnanthidium eutrophilum Lange-Bertalot & + & & & \\
\hline $\begin{array}{l}\text { Achnanthidium macrocephalum (Hustedt) Round \& } \\
\text { Bukhtiyarova }\end{array}$ & & & & + \\
\hline Achnanthidium microcephalum Kützing & + & & & \\
\hline Achnanthidium minutissimum (Kützing) Czarnecki & + & & & \\
\hline Achnanthidium pyrenaicum (Hustedt) H. Kobayasi & + & & & \\
\hline Achnanthidium subatomus (Hustedt) Lange-Bertalot & & & & + \\
\hline Amphora copulata (Kützing) Schoeman \& R.E.M. Archibald & + & & & \\
\hline
\end{tabular}


Table 3. Continue

\begin{tabular}{|c|c|c|c|c|c|}
\hline Localities & S1 & S2 & S3 & S4 & S5 \\
\hline Aulacoseira crassipunctata Krammer & + & & & & \\
\hline Cyclotella meneghiniana Kützing & + & & + & + & + \\
\hline Cymbella affinis Kützing & & & & & + \\
\hline Cymbella sp. & & + & & & \\
\hline Cymbopleura apiculata Krammer & + & & & & \\
\hline Cocconeis placentula Ehrenberg & + & & + & + & + \\
\hline Cocconeis pediculus Ehrenberg & & + & + & & + \\
\hline Delicata delicatula (Kützing) Krammer & + & & & & \\
\hline Diploneis elliptica (Kützing) Cleve & + & & & & + \\
\hline Diploneis ovalis (Hilse) Cleve & + & & & & \\
\hline Decussata placenta (Ehrenberg) Lange-Bertalot \& Metzeltin & + & & & + & \\
\hline Encyonema caespitosum Kützing & + & & & & \\
\hline Encyonema semilanceolatum Krammer & + & & & & \\
\hline Encyonema silesiacum (Bleisch) D.G. Mann & + & & + & + & + \\
\hline Encyonema simile Krammer & + & & & & \\
\hline Encyonema vulgare Krammer & + & & & & \\
\hline Fragilaria capucina Desmazières & + & & + & + & \\
\hline Fragilaria biceps Ehrenberg & + & & & + & \\
\hline Fragilaria vaucheriae (Kützing) J.B. Petersen & + & & + & + & + \\
\hline Gomphonella olivacea (Hornemann) Rabenhorst & & & + & & + \\
\hline Gomphonema parvulum (Kützing) Kützing & + & & + & + & + \\
\hline Gomphonema capitatum Ehrenberg & + & & & & \\
\hline Gomphonema subclavatum (Grunow) Grunow & + & & + & + & + \\
\hline Gomphonema tergestinum (Grunow) Fricke & & & + & & \\
\hline Hannaea arcus (Ehrenberg) R.M. Patrick & + & & + & + & + \\
\hline Lemnicola hungarica (Grunow) Round \& Basson & & & + & & \\
\hline Melosira varians C. Agardh & + & + & + & + & + \\
\hline Meridion circulare (Greville) C. Agardh & + & & + & + & + \\
\hline Navicula amphiceropsis Lange-Bertalot \& U. Rumrich & + & & & + & + \\
\hline Navicula capitatoradiata H. Germain ex Gasse & + & & + & + & + \\
\hline Navicula cryptocephala Kützing & + & & & & + \\
\hline Navicula gregaria Donkin & + & & & & \\
\hline Navicula lanceolata (C. Agardh) Kützing & + & + & + & + & + \\
\hline Navicula sp. & & + & & & \\
\hline Navicula tripunctata (O.F. Müller) Bory & & & & + & + \\
\hline Nitzschia dissipata (Kützing) Rabenhorst & & + & + & + & + \\
\hline Nitzschia palea (Kützing) W. Smith & + & & & & \\
\hline Nitzschia sp. 1 & & + & & & \\
\hline Nitzschia sp. 2 & & + & & & \\
\hline Nitzschia sp. 3 & & + & & & \\
\hline Nitzschia sp. 4 & & + & & & \\
\hline Nitzschia vermicularis (Kützing) Hantzsch & + & & & & \\
\hline Odontidium mesodon (Kützing) Kützing & + & + & + & & \\
\hline Placoneis anglophila (Lange-Bertalot) Lange-Bertalot & & & & & + \\
\hline Planothidium frequentissimum (Lange-Bertalot) Lange- & & & & + & \\
\hline
\end{tabular}

Bertalot 
Table 3. Continue

\begin{tabular}{|c|c|c|c|c|c|}
\hline Localities & S1 & $\mathbf{S 2}$ & S3 & S4 & S5 \\
\hline Planothidium dubium (Grunow) Round \& Bukhtiyarova & + & & & & + \\
\hline $\begin{array}{l}\text { Planothidium lanceolatum (Brébisson ex Kützing) Lange- } \\
\text { Bertalot }\end{array}$ & + & & + & + & + \\
\hline Pinnularia microstauron (Ehrenberg) Cleve & + & & & & \\
\hline Reimeria sinuata (W. Gregory) Kociolek \& Stoermer & + & + & + & + & + \\
\hline Stauroneis smithii Grunow & & & + & & \\
\hline Staurosira construens Ehrenberg & + & & & & \\
\hline Staurosirella pinnata (Ehrenberg) D.M.Williams and Round & & & + & & \\
\hline Surirella brebissonii Krammer \& Lange-Bertalot & + & & & & \\
\hline Tabularia fasciculata (C. Agardh) D. M. Williams \& Round & + & & & & \\
\hline Tabellaria flocculosa (Roth) Kützing & & & & & + \\
\hline Ulnaria ulna (Nitzsch) Compère & + & & & + & + \\
\hline \multicolumn{6}{|l|}{ Chlorophyta } \\
\hline Cladophora glomerata (Linnaeus) Kützing & & & & & + \\
\hline Microspora sp. & & & & & + \\
\hline Microspora amoena (Kützing) Rabenhorst & + & & + & & \\
\hline Ulothrix zonata (F. Weber \& Mohr) Kützing & + & & & & + \\
\hline Total number of taxa & 55 & 12 & 31 & 25 & 35 \\
\hline
\end{tabular}

Diatoms were the most common component of algal flora at all localities (Table 3 ). From the total number of Bacillariophyta, the largest (42 taxa) was recorded at S1, while the smallest was recorded at S2 locality (12 taxa). The highest number of taxa belonged to the genera Navicula (7), Nitzschia (7), and Achnanthidium (6).

At all locations, the following species were identified: Melosira varians, Navicula lanceolata and Reimeria sinuata. The taxa recorded in $80 \%$ of samples were Chamaesiphon incrustans, Leptolyngbya notata, Oscillatoria limosa, Planktolyngbya sp., Audouinella chalybea, Cyclotella meneghiniana, Cocconeis placentula, Encyonema silesiacum, Fragilaria capucina, F. vaucheriae, Gomphonema parvulum, G. subclavatum, Hannaea arcus, Meridion circulare, Navicula capitatoradiata, Nitzschia dissipata and Planothidium lanceolatum (Table $3)$.

In compared to results published by LAUŠEVIĆ (1993), during our research in autumn 2018, a smaller number of taxa were recorded in the Samokovska River, which is primarily a consequence of taking a smaller number of samples from a smaller number of localities, as well as one-time research. Previously reported finding of Batrachospermum sp. in the upper stream of the Samokovska River (SIMIĆ and ĐORĐEVIĆ, 2017) was not confirmed by our research, as well as the finding of Hydrurus foetidus (SIMIĆ et al., 2003). During our research, at all investigated localities, except $\mathrm{S} 2$, it has been confirmed the presence of red alga Audouinella chalybea that formed microscopic aggregations at S1 locality only. Taxonomy of this alga has often been a subject of consideration by algologists (NECCHI and ZUCCHI, 1995, 1997; NECCHI et al., 1993a, 1993b; ZUCCHI and NECCHI, 2003). According to ZUCCHI and NECCHI (2003), the reddish thalli of the alga represent the Audouinella genus while the bluegreen thalli represent a "Chantransia" stage in Batrachospermales and Thoreales development.

At all locations of the Samokovska River, except S2 locality, different morphological forms of macroalgae were recorded as follows: free filaments of Cladophora glomerata (S5, Figure 2A), tufts of $A$. chalybea (S1, Figure 2B), Microspora amoena (S1, S3, Figure 2C), 
and Ulothrix zonata (S1, S5, Figure 2D), mats of Microcoleus favosus (S1, S3, Figure 2E), and Vaucheria sp. (S1, Figure 2F) (Table 3).
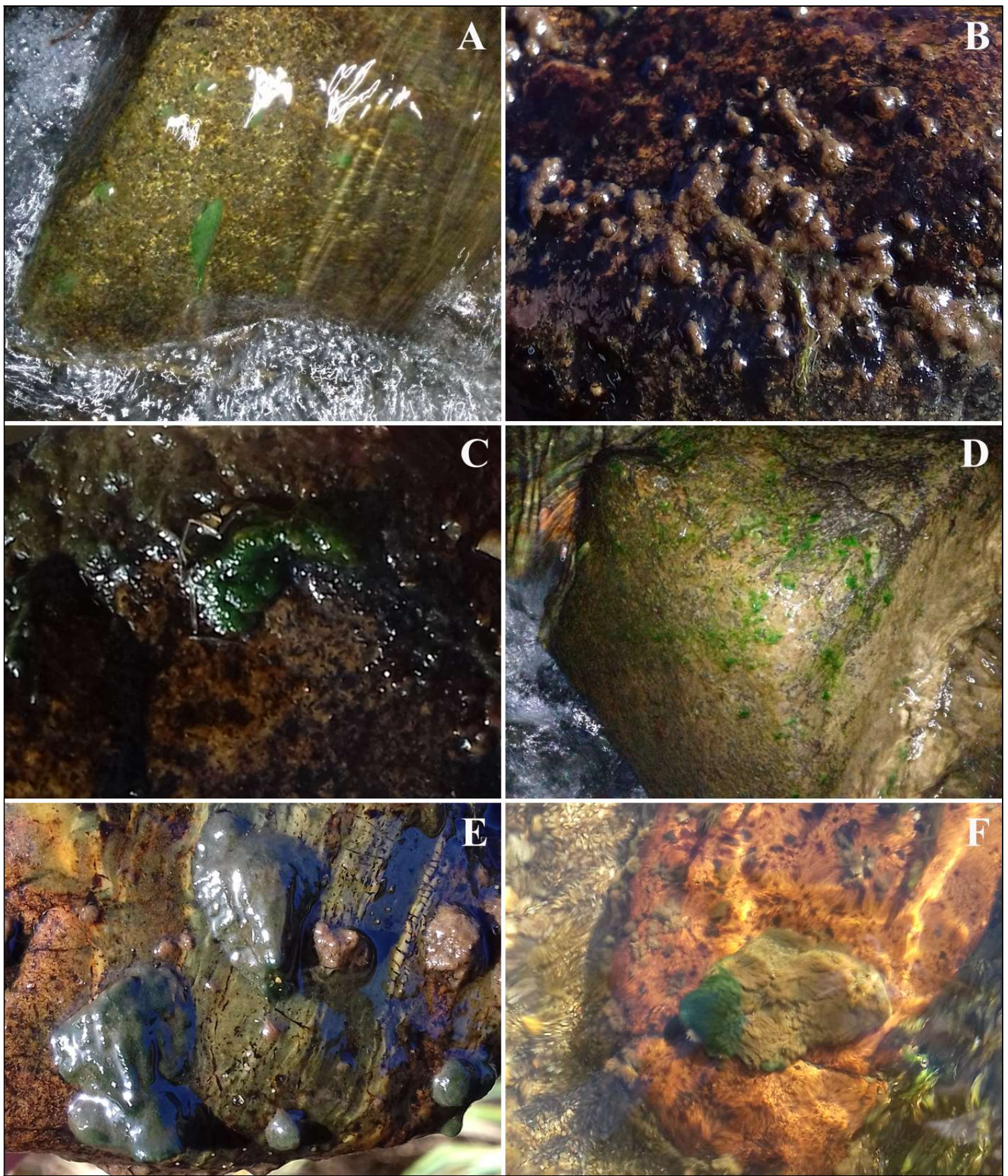

Figure 2. Benthic macroalgae found in the Samokovsa River; A) Cladophora glomerata; B) Audouinella chalybea; C) Microspora amoena; D) Ulothrix zonata; E) Microcoleus favosus; F) Vaucheria sp. (photos by A. Mitrović, 2018).

\section{Ecological status assessment}

Based on analysis of physico-chemical parameters, prescribed by the National Regulation (ANONYMOUS, 2011b) ecological status of the Samokovska River for surface 
water of Type 6 could be assessed as high (class I) at S1 and as good (class II) at S3, S4 and S5 localities (Tables 2, 4).

Based on analysis of parameters of phytobenthos as a biological quality element, the ecological status of the Samokovska River could be assessed as high (class I) at S3 (IPS=16.1) and S4 (IPS=14.9) localities and as good (class II) at S1 (IPS=13.8) and S5 (IPS=13.3) localities (Table 4).

The ultimate ecological status assessment based on biological and supporting physicochemical quality elements indicate that at all investigated localities the ecological status was good (class II) (Table 4).

Table 4. Ecological status assessment (ESA) of the Samokovska River based on physico-chemical and biological quality elements in October 2018 (water body Type 6).

\begin{tabular}{lllll}
\hline \multicolumn{1}{c}{ Localities } & S1 & S3 & S4 & S5 \\
ESA & & & & \\
\hline Class based on physico-chemical quality element & I & II & II & II \\
Class based on biological quality element & II & I & I & II \\
Ultimate ESA class & II & II & II & II \\
Ultimate ESA & good & good & good & good \\
\hline
\end{tabular}

Based on analysis of physico-chemical parameters, prescribed by the National Regulation (ANONYMOUS, 2011b) ecological status of the Samokovska River for water body Type 4 could be assessed as high (class I) at S1, as good (class II) at S4 and S5, and as moderate (class III) at S3 locality (Tables 2, 4).

Based on analysis of parameters of phytobenthos as a biological quality element, the ecological status of the Samokovska River could be assessed as high (class I) at S3 (IPS=16.1; $\mathrm{CEE}=13.4$ ), as good (class II) at S4 (IPS=14.9; $\mathrm{CEE}=12.3$ ), and as moderate (class III) at S1 (IPS=13.8; CEE=11.5), and S5 (IPS=13.3; CEE=10.8) localities (Table 5).

The ultimate ecological status assessment based on biological and supporting physicochemical quality elements indicate that ecological status was good (class II) at S4 and moderate (class III) at S1, S3 and S5 localities (Table 5).

Table 5. Ecological status assessment (ESA) of the Samokovska River based on physico-chemical and biological quality elements in October 2018 (water body Type 4).

\begin{tabular}{lcccc}
\hline \multicolumn{1}{c}{ Localities } & S1 & S3 & S4 & S5 \\
ESA & & & & \\
\hline Class based on physico-chemical quality element & I & III & II & II \\
Class based on biological quality element & III & I & II & III \\
Ultimate ESA class & III & III & II & III \\
Ultimate ESA & moderate & moderate & good & moderate \\
\hline
\end{tabular}

Our results of IPS diatom index showed worst ecological status classess than CEE diatom index. Many authors claim that IPS index is more trustworthy for ecological status assessment, comparing to the CEE index (VIDAKOVIĆ, 2013; VASILJEVIĆ et al., 2014, 2016, 2017; JAKOVLJEVIĆ et al., 2016a, 2016b; PREDOJEVIĆ, 2017; VASILJEVIĆ, 2017), primarily because it principally integrates most identified diatom species in contrast to CEE index. According to the National Regulation (ANONYMOUS, 2011b), there are no difference in the boundary values between classes for the CEE index for water body types, so changing its boundary values is suggested (VASILJEVIĆ, 2017). 
The level of reliability of ecological status assessment of the Samokovska River could be labeled as low, since for ecological assessment have not been used all relevant parameters of recommended quality elements and because the frequency of monitoring is lower than the minimum predicted.

According to the WFD (WFD, 2000), non-diatom benthic algae, including macroalgae, are recommended as useful biological quality elements, but the methodology of their usage in ecological status assessment has not been established in Serbia so far. However, their indication of water saprobity could correspond to classes of ecological status. Thus, red alga Audouinella chalybea is an indicator of oligosaprobic water, with low taxon indicator weight (SLÁDEČEK, 1973; PÁL, 1998). In Serbia, the species was found in oligosaprobic, but also in ß-mesosaprobic waters (CVIJAN and BlAŽENČIĆ, 1986; CVIJAN, 2002; CVIJAN et al., 2003; Simić et al., 2016). Cyanobacteria Microcoleus favosus and green alga Cladophora glomerata are an indicator of $\beta$-mesosaprobic water, whereby $M$. favosum possess a high and $C$. glomerata a low taxon indicator weight (SLÁDEČEK, 1973; PÁL, 1998). According to SLÁDEČEK (1973) and PÁL (1998), green alga Microspora amoena is characterized as an indicator of xenosaprobic or oligosaprobic water, but its higher value of saprobic valence is in Bmesosaprobic degree and possesses a low taxon indicator weight. Green alga Ulothrix zonata is presented by two types from which one represents an indicator of oligosaprobic, and the second as an indicator of $\alpha$-mesosaprobic water, both with a high taxon indicator weight (SLÁDEČEK, 1973; PÁL, 1998).

In comparison to the previous assessment of the degree of water saprobity (LAUŠEVIĆ, 1992), our results indicate deterioration of water quality of the Samokovska River. According to the water quality assessment based on macroalgae, the Samokovska River better corresponds to water body Type 4 . Negative anthropogenic influences noticed in the field also support our inference.

\section{Treatening factors}

This river is threatened by various anthropogenic influences, such as an inadequately regulated sewage network in the area of the National Park Kopaonik, so a large number of sewers drains outflow into the Samokovska River and its tributaries. Results of physicochemical and biological quality elements do not indicate the water pollution since our research was conducted in October when the accommodation capacities within the tourist complex are unfilled, so the pressure of sewage was not prominent. This confirmed that onetime research results give us only a current picture of environmental conditions.

However, disappearance of stenovalent red alga Batrachospermum sp. (SIMIć and ĐORĐEVIĆ, 2017) and golden alga Hydrurus foetidus (SIMIĆ et al., 2003) from the Samokovska River is not unexpected. The habitat of these algae has changed significantly in recent years. Intensive deforestation, pollution, and turbidity of water have conditioned the disappearance of these rare algae, creating conditions for more intensive development of competitive filamentous algae.

A small HPP "Samokovska reka 1" (Fig. 1C), located in the zone of II and III protection degrees can be singled out as an important threatening factor. Small HPPs are a negative anthropogenic factor known to cause immeasurable environmental damages on lotic ecosystems that may lead to long-term changes in the benthic algal communities, especially regarding stenovalent species (WU et al., 2010; LIERMANN et al., 2012; RISTIĆ et al., 2018; WIATKOWSKI and TOMCZYK, 2018; MITROVIĆ et al., 2021).

Since the Samokovska River is the most important watercourse in the National Park Kopaonik, for trustworthy assessment of water quality of the Samokovska River, at least three times per year monitoring is necessary, but also use of all predicted parameters of biological 
and physico-chemical quality elements. The untrustworthy typology problem of this river is also necessary to be solved for further research.

\section{Acknowledgments}

The authors would like to thank the National Park Kopaonik, which enabled field research. This work was supported by the Serbian Ministry of Education, Science and Technological Development (Agreement No. 451-03-9/2021-14/200122).

\section{References:}

[1] ANDREJIĆ, J. (2012): Floristic-ecological analysis of (Bacillariophyta) from the Nišava River and tributaries Jerma and Temska Rivers. PhD thesis, Faculty of Biology, Belgrade. [in Serbian]

[2] AnONYMOUS (1981): Zakon o Nacionalnom parku Kopaonik (Sl. glasnik RS 41/1981). [in Serbian]

[3] ANONYMOUS (2010b): Pravilnik o utvrđivanju vodnih tela površinskih i podzemnih voda (Sl. glasnik RS 96/2010). [in Serbian]

[4] ANONYMOUS (2011b): Pravilnik o parametrima ekološkog i hemijskog statusa površinskih voda i parametrima hemijskog i kvantitativnog statusa podzemnih voda (Sl. glasnik RS 74/2011). [in Serbian]

[5] ANONYMOUS (2016): Prostorni plan područja posebne namene NP Kopaonik (Sl. glasnik RS 89/2016) [in Serbian]

[6] Cemagref (1982): Etude des méthodes biologiques quantitative d'appréciation quantitative de la qualité des eaux. Rapport Division Qualité des Eaux Lyon Agence financière de Bassin Rhône-Méditerranée-Corse, Pierre-Bénite, 218 pp.

[7] CviJAn, M. (2002): Material for the algae flora of Serbia. II: Rhodophyta (Red Algae), Review. Archives of Biological Sciences 54 (1-2): 1-10. doi: 10.2298/ABS0202001C

[8] CVIJAn, M., BlažEnČić, J. (1986): New findings of Chantransia chalybea (Lyngb.) Fries (Rhodophyta) in SR Serbia. Glasnik Instituta za Botaniku i Botaničke bašte Univerziteta u Beogradu 20: 75-79. [in Serbian]

[9] Cvijan, M., BlažEnČıć, J., SubaKov-Simić, G. (2003): Serbian algal flora 2 - Rhodophyta. NNK international, Belgrade. [in Serbian]

[10] Descy, J.P., Coste, M. (1991): A test methods for assessing water quality based on diatoms. Verhandlung Internationale Vereingung de Limnologie 24: 2112-2116.

[11] Eloranta, P., Kwandrans, J., Kusel-Fetzmann, E. (2011): Rhodophyceae and Phaeophyceae. - In: Budel, B., Gartner, G., Krienitz, L., Preisig, H.R., Schagerl, M. (eds.) Freshwater flora of Central Europe, Spektrum Akademischer Verlag, pp. 1-155.

[12] EN 13946 (2015): Water quality - Guidance standard for the routine sampling and pretreatment of benthic diatoms from rivers. Institute for Standardization of Serbia.

[13] EN 14407 (2015): Water quality - Guidance standard for the identification and enumeration of benthic diatom samples from rivers and lakes. Institute for Standardization of Serbia. 
[14] EN 5667 (part 1-19) (2017): Water quality - Sampling. Institute for Standardization of Serbia.

[15] JAKOVLJEVIĆ, O. (2019): Epilithic diatom communities - seasonal dynamics and ecological status assessment of selected rivers from the eastern and southeastern Serbia. $P h D$ thesis, Faculty of Biology, Belgrade. [in Serbian]

[16] Jakovljević, O.S., Popović, S.S., Vidaković, D.P., Stojanović, K.Z., Krizmanić, J.Ž. (2016a): The application of benthic diatoms in water quality assessment (Mlava River, Serbia). Acta Botanica Croatica 75 (2): 199-205. doi: 10.1515/botcro-2016-0032

[17] Jakovljević, O., Popović, S., Živić, I., Stojanović, K., Krizmanić, J. (2016b): Benthic diatoms of the Vrla River (Serbia) and their application in the water ecological status assessment. Oceanological and Hydrobiological Studies 45 (3): 304-315. doi: 10.1515/ohs-2016-0029

[18] John, D.M., Whitton, B.A., Brook, A.J. (2011): Freshwater algal flora of the British Isles. Cambridge University Press, Cambridge.

[19] KomÁreK, J., Anagnostidis, K. (1999): Cyanoprokaryota 1. Teil: Chroococcales. - In: Ettl H., Gärtner G., Heynig H., Mollenhauer D. (eds.) Süßwasserflora von Mitteleuropa, Spektrum Akademischer Verlag 19/1: 1-548.

[20] KomÁreK, J., Anagnostidis, K. (2005): Cyanoprokaryota 2. Teil: Oscillatoriales - In: Büdel, B., Gärtner, G., Krienitz, L., Schagerl, M. (eds.) Süßwasserflora von Mitteleuropa, Spektrum Akademischer Verlag: 19/2: 1-759.

[21] KRIZMANIĆ, J. (2009): Floristic, taxonomic and ecological research of silicate algae with raphe (Bacillariophiceae, Bacillariophycideae, Bacillariophita) of Serbia. PhD thesis, Faculty of Biology, Belgrade. [in Serbian]

[22] LAUŠEvić, R. (1992): Saprobiological analysis of the Samokovska River (Kopaonik, Serbia). Zaštita voda '92, Jugoslovensko društvo za zaštitu voda: 156-162.

[23] LAUŠEvić R. (1993): Floristic composition of algae in the Samokovska river. Archives of Biological Sciences 45 (3-4): 125-136.

[24] LAUŠEviĆ R., CVIJAN M. (1996): A check-list of the algae of the Kopaonik mountain. Ekologija 31 (1): 17-42.

[25] Lecointe, C., Coste, M., Prygiel, J. (1993): Omnidia: software for taxonomy, calculation of diatom indices and inventories management. Hydrobiologia 269/270: 509-513.

[26] Liermann, C.R., Nilsson, C., Robertson, J., NG, R.Y. (2012): Implications of dam obstruction for global freshwater fish diversity. BioScience 62: 539-548. doi: 10.1525/ BIO.2012.62.6.5.

[27] MCCORMick, P.V., CAIRns, J. (1994): Algae as Indicators of Environmental Change. Journal of Applied Phycology 6: 509-526. doi: 10.1007/BF02182405

[28] Mitrović, B.A., ĐorĐević B.N., Simić B.S. (2021): A review of research on the Lemanea genus in Serbia. Oceanological and Hydrobiological Studies 50 (1): 47-59. doi: 10.2478/oandhs-2021-0006

[29] NeCCHI, O.JR., ZuCCHI, M.R. (1995): Systematics and distribution of freshwater Audouinella (Acrochaetiaceae, Rhodophyta) in Brazil. European Journal of Phycology 30: 209-218. 
[30] NeCCHI, O.JR., ZuCCHI, M.R. (1997): Audouinella macrospora (Achrochaetiacea, Rhodophyta) is the Chantransia stage of Batrachospermum (Batrachospermaceae). Phycologia 36 (3): 220-224.

[31] Necchi, O.Jr., Sheath, R.G., Cole, K.M. (1993a): Systematics of freshwater Audouinella (Rhodophyta, Acroachaetiaceae) in North America. 1. The reddish species. Algological Studies 70: 11-28.

[32] Necchi, O.JR., Sheath, R.G., Cole, K.M. (1993b): Systematics of freshwater Audouinella (Rhodophyta, Acroachaetiaceae) in North America. 2. The bluish species. Algological Studies 71: 13-21.

[33] Poikane, S., Kelly, M., Cantonati, M. (2016): Benthic algal assessment of ecological status in European lakes and rivers: Challenges and opportunities. Science of the Total Environment 568: 603-613.

[34] Predojević, D. (2017): Ecological status assessment of the Zasavica River based on algological parameters. PhD thesis. Faculty of Biology, Belgrade. [in Serbian]

[35] PÁL, G. (1998): Szaprobiológiai indikátor fajok jegyzéke. Vízi természet-és környezetvédelem.

[36] Ristić, R., Malušević, I., Polovina, S., Milčanović, V., Radić, B. (2018): Small hydropower plants - derivation type: insignificant energy benefit and immeasurable environmental damage. Vodoprivreda 50 (294-296): 311-317. [In Serbian with English summary]

[37] Simić, S. (2002): Macroalgae in streams of hill-mountain areas of Serbia. PhD thesis, Faculty of Biology, Belgrade. [in Serbian]

[38] Simić, S., Ranković, B., CviJan, M. (2003): Distribution of Hydrurus foetidus (Vill.) Kirch. (Chrysophyta) species in highland streams of Serbia. Third International Balkan Botanical Congress. Book of Abstracts, p. 77, Sarajevo, Bosnia and Herzegovina.

[39] Simić, B.S., DJordJević, B.N., Mitrović, B.A. (2016): Diversity of algae in protected natural habitats - the Mlava springhead and the Krupaj springhead. $2^{\text {nd }}$ International Symposium on Nature Conservation, "Nature Conservation - experiences and perspectives ", Book of Proceedings. Institute for Nature Conservation of Vojvodina Province, Novi Sad: 105-117.

[40] Simić, B.S., ĐorĐeVIĆ B.N. (2017): New data on distribution and ecology of Batrachospermum (Rhodophyta) in Serbia. Botanica Serbica 41 (1): 65-70.

doi: $10.5281 /$ zenodo.45442

[41] SLÁDEČEK, V. (1973): System of water quality from the biological point of view. Archiv für Hydrobiologie - Beiheft: Ergebnisse der Limnologie, Stuttgart, E. Schweizebatsche Verlagstbuchhandlung 7: 1-218.

[42] VAsiljević, B. (2017): Benthic diatoms (Bacillariophyta) in assessment of the ecological status of the Velika Morava and Sava rivers. PhD thesis. Faculty of Science, Kragujevac. [in Serbian]

[43] Vasiljević, B., Krizmanić, J., Ilić, M., Marković, V., Tomović, J., Zorić, K., PAUNOVIĆ, M. (2014): Water quality assessment based on diatom indices - small hilly streams case study. Water Research and Management 4 (2): 31-35.

[44] Vasiljević, B., Simić, B.S., Paunović, M., Marinković, N., Đikanović, V., KračunKolareviĆ, M., ANĐUS, S. (2016): Diatom based assessment of the ecological status of the Sava River - 2014 case study. Book of abstracts $1^{\text {st }}$ GLOBAQUA International 
Conference "Managing the Effects of Multiple Stressors on Aquatic Ecosystems Under Water Scarcity”, Freising (Germany): 98-99.

[45] Vasiljević, B., Simić, B.S., Paunović, M., Zuliani, T., Krizmanić, J., Marković, V., TOMOVIĆ, J. (2017): Contribution to the improvement of diatom-based assessments of the ecological status of large rivers - The Sava River Case Study. Science of The Total Environment 605-606: 874-883. doi: 10.1016/j.scitotenv.2017.06.206.

[46] VAsović, M. (1988): Kopaonik. Stručna knjiga, Beograd.

[47] VidAKOviĆ, D. (2013): Assessment of the ecological status assessment of Raška River based on epilithic diatoms. Unpublished master thesis. Faculty of Biology, Belgrade. [in Serbian]

[48] WFD (2000): Water Framework Directive - Directive of European Parliament and of the Council 2000/60/EC - Establishing a Framework for Community Action in the Field of Water Policy.

[49] Wiatkowski, M., TOMCZYK, P. (2018): Comparative assessment of the hydromorphological status of the rivers Odra, Bystrzyca, and sleza using the RHS, LAWA, QBR, and HEM methods above and below the hydropower plants. Water 10: 116. doi: $10.3390 / \mathrm{w} 10070855$.

[50] Wehr, J.D., Sheath, R.G., Kociolek, J.P. (2015): Freshwater algae of North America, ecology and classification. Academic Press, San Diego.

[51] Wu, N.C., JiAnG, W.X., Fu, X.C., ZhOU, S.C., LI, F.Q. et al. (2010): Temporal impacts of a small hydropower plant on benthic algal community. Fundam. Appl. Limnol. 177 (4): 257-266. doi: 10.1127/1863-9135/2010/0177-0257.

[52] ZuCCHI, M.R., NeCCHI, O.RJ. (2003): Blue-greenish acrochaetioid algae in freshwater habitats are 'Chantransia' stages of Batrachospermales "sensu lato" (Rhodophyta). Cryptogamie Algologie 24: 117-131. 